\title{
NEW ZEALAND FLOWER THRIPS AND THEIR IMPACT ON NECTARINE FRUIT DISEASES
}

\author{
G.F. McLAREN ${ }^{1}$, J.A. FRASER ${ }^{1}$ and P.A. ALSPACH ${ }^{2}$ \\ ${ }^{1}$ HortResearch, Clyde Research Centre, R.D. 1 Alexandra, Central Otago, \\ New Zealand \\ ${ }^{2}$ HortResearch, Nelson Research Centre, P.O. Box 220, Motueka, New Zealand \\ Corresponding author: JMcLaren@hortresearch.co.nz
}

\begin{abstract}
Insecticides, fungicides and a bactericide were applied in spring 2001 and 2002 to nectarine trees, to determine the impact of thrips (mainly New Zealand flower thrips, Thrips obscuratus) on summerfruit pathogens. Thrips numbers were assessed over 7 weeks from the beginning of flowering. The insecticide programme increased the proportion of fruit meeting export standards for thrips damage, but did not influence the level of either brown rot, caused by Monilinia fructicola, or the bacterial diseases, bacterial blast (Pseudomonas syringae) and bacterial spot (Xanthomonas arboricola pv. pruni). The fungicide programme reduced the level of brown rot. Cumulative thrips counts were positively correlated with levels of brown rot infection on the fruit at harvest time in 2001/02 $(\mathrm{P}=0.02)$ and 2002/03 $(\mathrm{P}=0.09)$, and bacterial disease symptoms in 2001/ $02(\mathrm{P}=0.03)$. It was concluded that New Zealand flower thrips could increase levels of disease in nectarines but the value of treating with insecticides was not clear.

Keywords: disease vectors, brown rot, Monilinia fructicola, bacterial blast, Pseudomonas syringae, bacterial spot, Xanthomonas arboricola pv. pruni.
\end{abstract}

\section{INTRODUCTION}

Thrips (Thripidae) damage some horticultural crops by their feeding, and are also reported to act as vectors of diseases, particularly tospoviruses (Mound 2002) and fungal and bacterial pathogens (Bailey 1935; Ananthrakrishnan 1980). However, there appears to be limited experimental evidence to support the claim that thrips can vector bacteria or fungi. Lewis (1973) listed four economically important bacteria that had been found on the bodies of thrips, but considered the impact of thrips as disease vectors to be minor. It is assumed that the pathogens enter the host plant through punctures caused by thrips feeding and oviposition. Some thrips species have been shown to feed on fungal spores, but fungi appear to be an uncommon food source for Thripidae (Marullo 1997).

Teulon \& Penman (1994) listed eleven species of thrips that have been associated with damage to nectarines worldwide. Two of these, the endemic New Zealand flower thrips Thrips obscuratus (Crawford) (NZFT) and western flower thrips, Frankliniella occidentalis (Pergande) (WFT), are present in New Zealand. Nectarines appear to be particularly susceptible to damage by thrips, since NZFT has not been reported to cause damage to any other commercial host plants within its wide host range. In New Zealand, WFT has not been recorded from nectarine flowers, but adults collected from lupin (Lupinus arboreus) caused damage to fruitlets after they had been bagged on nectarine flowers (McLaren 1992). NZFT has not been recorded as a vector of tospoviruses in New Zealand but it has been confirmed as a vector of Botrytis cinerea Pers. in kiwifruit flowers, leading to increased fruit infection levels at harvest (Fermaud et al. 1994; Fermaud \& Gaunt 1995; Michailides \& Elmer 2000). Ellis et al. (1988) demonstrated that NZFT can act as a passive vector for spores of brown rot Monilinia fructicola (G. 
Wint.) Honey but did not demonstrate that spores transported by NZFT increased the level of brown rot in stonefruit at harvest.

The purpose of this study was to evaluate the possible role of NZFT in the spread of diseases in spring in commercially grown nectarines. The 6-8 week period of concern includes two distinct phases, with adults of the first generation feeding on nectarine flowers and those of the second generation feeding on fruitlets in the ten day period between petal fall and shuck fall (McLaren \& Fraser 2000). While NZFT adults are feeding on nectarine flowers and fruitlets they have the potential to spread three important diseases, the brown rot fungus and two bacterial diseases, bacterial blast (Pseudomonas syringae pv. syringae van Hall) and bacterial spot (Xanthomonas arboricola pv. pruni (Smith)).

\section{METHODS}

The trials were conducted during 2001/02 and 2002/03 on a block of mature nectarines cv. Fantasia growing at HortResearch, Clyde Research Centre, Central Otago. Two factorial trials of similar design investigated the effect of fungicide, insecticide and bactericide (Table 1), each at two levels (none and the recommended programme) alone and in combination. In the first year, the trial was designed with four replicates of eight treatments with four trees per plot, and in the second year there were three replicates of single-tree plots. Treatments were applied with a pressurized handgun, applying 6 litres/tree (2000 litres/ha), between bloom and shuck fall in both years (Table 1).

TABLE 1: Dates and rates of application of fungicides, bactericides and insecticides in spring 2001 and 2002.

\begin{tabular}{|c|c|c|c|c|}
\hline Year & Tree stage & Fungicide & Bactericide & Insecticide \\
\hline \multicolumn{5}{|l|}{2001} \\
\hline 19 September & $90 \%$ bloom & tebuconazole $^{1}$ & copper hydroxide ${ }^{3}$ & taufluvalinate $^{4}$ \\
\hline 1 October & $90 \%$ petal fall & tebuconazole & copper hydroxide & chlorpyrifos $^{5}$ \\
\hline 12 October & $100 \%$ petal fall & tebuconazole & copper hydroxide & chlorpyrifos \\
\hline 23 October & early shuck fall & tebuconazole & copper hydroxide & chlorpyrifos \\
\hline \multicolumn{5}{|l|}{2002} \\
\hline 9 September & $10 \%$ bloom & tebuconazole & & \\
\hline 16 September & $80 \%$ bloom & cyprodinil $^{2}$ & & taufluvalinate \\
\hline 17 September & & & copper hydroxide & \\
\hline 27 September & $30 \%$ petal fall & cyprodinil & copper hydroxide & \\
\hline 7 October & & - & copper hydroxide & \\
\hline 17 October & & - & & chlorpyrifos \\
\hline
\end{tabular}

${ }^{1}$ Folicur (10 g ai/100 litres).

${ }^{2}$ Chorus (15 g ai/100 litres).

${ }^{3}$ Kocide 2000 DF (10.5 g ai/100 litres).

${ }^{4}$ Mavrik (4.8 g ai/100 litres).

${ }^{5}$ Lorsban $750 \mathrm{WG}$ (24.8 g ai/100 litres).

Thrips abundance during flowering was assessed weekly by tapping 20 branches per tree and collecting thrips in a yellow plate held under the branch (McLaren \& Fraser 2000). Two trees per plot were sampled on seven occasions between $80 \%$ bloom on 18 September 2001 and shuck fall on 30 October 2001. In 2002, each tree was sampled 10 times between $20 \%$ bloom on 11 September and late shuck fall on 6 November. In both years, $90 \%$ petal fall occurred on 2 October. All thrips were collected and identified under a binocular microscope.

In both years 100 fruit were picked from each plot at harvest time and graded for thrips and bacterial damage. For thrips damage, fruit were classed as export grade if the 
russetted area was $<0.75 \mathrm{~cm}^{2}$ or less than $1 \mathrm{~cm}$ long, or reject grade if the russetting covered a greater area. Bacterial damage was assessed as either present or absent, and no attempt was made to separate between the symptoms of bacterial blast and bacterial spot. The bacterial pathogens were identified from the fruit by R. Taylor (HortResearch, Mt Albert Research Centre) using PCR-based methods and colony morphology on Kings $\mathrm{B}$ media in both years. The number of brown rot-infected fruit on each tree was assessed in the field on a presence/absence basis three days before harvest in 2002. In the following season, few fruit infections developed in the field and brown rot was assessed postharvest. For this, 50-55 fruit were harvested per plot and packed in a single layer, wrapped in a plastic bag inside a crate and stored at $0^{\circ} \mathrm{C}$ for 7 days. The fruit were then held at ambient for a further 6 days, before being assessed once for the presence or absence of brown rot.

The proportion of fruit at harvest (a) not meeting export standards for thrips damage, (b) with bacterial infection and (c) that developed brown rot were analysed using the S-Plus programme. The relationship between thrips numbers and the amount of disease was investigated in a cumulative approach comparing firstly thrips catch in week 1 , then weeks $1+2$ and so on using scatterplots and correlation analysis. This approach allowed a focus on the sensitive flowering period of the crop. The linear correlation coefficients between the amount of disease and thrips numbers were computed for the plots without insecticides (for thrips damage), without fungicide (for brown rot) and without copper (for bacterial diseases).

\section{Thrips species}

\section{RESULTS}

The predominant thrips found on nectarines in both years was NZFT. In $200123 \%$ of specimens were other species compared with only $0.6 \%$ in 2002 (Table 2).

TABLE 2: Thrips species identified from samples collected from nectarines in spring in the Alexandra/Clyde district in 2001 and 2002.

\begin{tabular}{lcc}
\hline & 2001 & 2002 \\
\hline Thrips obscuratus & 188 & 1058 \\
Frankliniella occidentalis & 2 & 2 \\
Thrips tabaci & 15 & 0 \\
Haplothrips kurdjumovi & 7 & 2 \\
Chirothrips manicatus & 30 & 2 \\
Limothrips cerealium & 3 & 0 \\
\hline
\end{tabular}

\section{Bacteria}

A mix of both bacterial blast and bacterial spot caused bacterial symptoms on the fruit in 2002, but all the symptoms were caused by bacterial blast alone in 2003 (R. Taylor, pers. comm.).

\section{Effect of treatments}

The insecticide programme reduced thrips numbers by $80 \%$ from $2.0( \pm 0.25)$ thrips/tree/day to $0.4( \pm 0.05)$ between flowering and shuck fall in $2001 / 02(\mathrm{P}<0.001)$ and by $76 \%$ from $1.64( \pm 0.31)$ to $0.39( \pm 0.08)$ thrips/tree/day in $2002 / 03$.

The insecticide programme increased the level of export-grade fruit from 59.6 to $80.1 \%$ (SED=5.19\%) in 2001/02 and from 57.2 to $80.8 \%$ (SED=4.20\%) in 2002/03. The insecticide programme did not reduce the level of bacterial symptoms on the fruit in either year, nor did it reduce the level of brown rot (Table 3). The fungicide programme reduced fruit rots at harvest in both years (Table 3 ). In contrast, the bactericide programme did not reduce the incidence of bacterial symptoms on the fruit at harvest in either year (Table 3). Bacterial incidence was higher in 2001/02. There were no significant interactions between the insecticides, fungicides or bactericides $(\mathrm{P}>0.05)$. 
TABLE 3: Mean percentage of fruit with thrips damage and bacterial and brown rot symptoms at harvest.

\begin{tabular}{|c|c|c|c|c|c|c|}
\hline & \multicolumn{2}{|c|}{ Thrips damage } & \multicolumn{2}{|c|}{ Bacterial symptoms } & \multicolumn{2}{|c|}{ Brown rot } \\
\hline & $(\%)$ & $\mathrm{P}_{\text {-value }}{ }^{1}$ & $(\%)$ & P-value ${ }^{1}$ & $(\%)$ & $\bar{P}$-value ${ }^{1}$ \\
\hline \multicolumn{7}{|l|}{$2001 / 2002$} \\
\hline No fungicide & 31.5 & & 68.5 & & 26.7 & \\
\hline Fungicide & 28.9 & 0.614 & 65.6 & 0.569 & 11.9 & 0.003 \\
\hline No insecticide & 40.4 & & 65.3 & & 19.0 & \\
\hline Insecticide & 19.9 & 0.001 & 68.8 & 0.501 & 19.5 & 0.913 \\
\hline No bactericide & 28.2 & & 63.3 & & 19.9 & \\
\hline Bactericide & 32.1 & 0.460 & 70.8 & 0.154 & 18.6 & 0.771 \\
\hline SED & 5.19 & & 5.12 & & 4.50 & \\
\hline \multicolumn{7}{|l|}{$2002 / 2003$. } \\
\hline No fungicide & 30.0 & & 14.0 & & 12.4 & \\
\hline Fungicide & 32.0 & 0.630 & 12.5 & 0.749 & 2.5 & 0.016 \\
\hline No insecticide & 42.8 & & 12.4 & & 7.5 & \\
\hline Insecticide & 19.2 & 0.000 & 14.0 & 0.722 & 7.3 & 0.956 \\
\hline No bactericide & 34.6 & & 13.3 & & 9.2 & \\
\hline Bactericide & 27.4 & 0.108 & 13.2 & 0.993 & 5.7 & 0.362 \\
\hline SED & 4.20 & & 4.42 & & 3.65 & \\
\hline
\end{tabular}

${ }^{1} \mathrm{P}$-values for comparison between no fungicide and fungicide, no insecticide and insecticide or no bactericide and bactericide.

\section{Thrips and diseases}

Cumulative thrips numbers per tree (starting with counts during flowering) were compared with disease levels on fruit from trees that had received no treatment (Table 4). The correlation between thrips numbers and brown rot levels increased until 10 October 2001 and 11 October 2002, then declined. The correlation in $2001(\mathrm{r}=0.58, \mathrm{P}=0.02)$ was similar to that in 2002 ( $\mathrm{r}=0.51, \mathrm{P}=0.09)$. Using the same procedure, a significant correlation was found between thrips counts in 2001 and bacterial symptoms at harvest, but the correlation was not significant in 2002 (Table 4). High cumulative thrips numbers by mid-October were associated with higher levels of thrips damage in both years (Table 4).

TABLE 4: Linear correlation coefficients between the sum of thrips numbers (up to different dates) and thrips damage, bacterial symptoms and brown rot.

\begin{tabular}{ccccc}
\hline \multicolumn{2}{c}{$\begin{array}{c}\text { Cumulative thrips numbers } \\
\text { to: }\end{array}$} & Thrips damage & Bacterial symptoms & Brown rot \\
\hline 2001 & 24-Sep & 0.25 & $0.50^{* 1}$ & 0.39 \\
03-Oct & 0.40 & $0.48^{*}$ & $0.60^{*}$ \\
10-Oct & 0.31 & $0.54^{*}$ & $0.58^{*}$ \\
17-Oct & $0.52^{*}$ & $0.55^{*}$ & $0.49^{*}$ \\
26-Oct & $0.47^{*}$ & $0.51^{*}$ & 0.34 \\
& 30-Oct & 0.45 & $0.51^{*}$ & 0.33 \\
& 20-Sep & $0.55^{*}$ & 0.17 & 0.10 \\
27-Sep & $0.57^{*}$ & 0.13 & 0.05 \\
02-Oct & $0.56^{*}$ & 0.19 & 0.32 \\
09-Oct & $0.70^{*}$ & 0.27 & 0.48 \\
11-Oct & $0.67^{*}$ & 0.27 & $\left.0.51^{*}\right)$ \\
16-Oct & $0.66^{*}$ & 0.20 & 0.37 \\
23-Oct & $0.67^{*}$ & 0.18 & 0.31 \\
& 30-Oct & $0.81^{*}$ & 0.01 & 0.30 \\
& 06-Nov & $0.81^{*}$ & -0.12 & 0.23 \\
\hline
\end{tabular}

${ }^{*}$ Significant correlations at $\mathrm{P}<0.05 .{ }^{2}$ Significant correlation at $\mathrm{P}=0.09$. 
In 2001/02, a cumulative count of 1 thrips/tree by 10 October was associated with approximately $20 \%$ brown rot and $60 \%$ bacterial infection (Fig. 1). When cumulative numbers increased to 10 thrips/tree, approximately $45 \%$ of the fruit developed brown rot and $80 \%$ bacterial infections (Fig. 1). However, these figures were less in 2002 (Fig. 1).
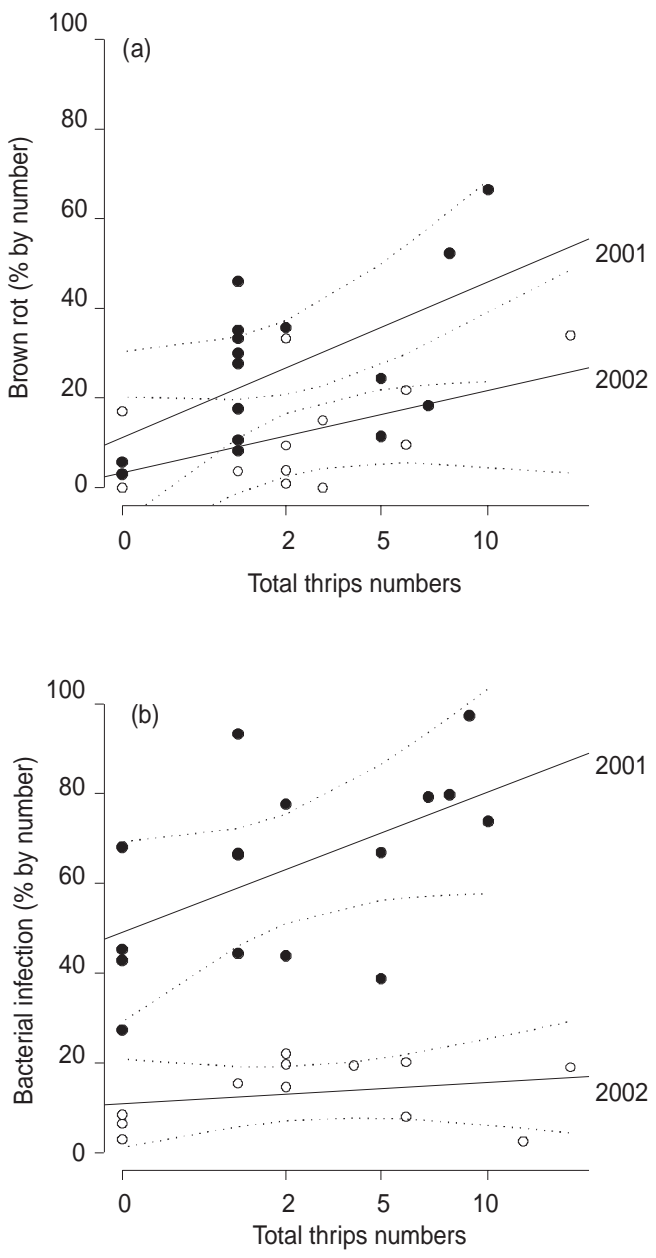

FIGURE 1: Relationship between cumulative numbers of thrips per tree to 10 October 2001 (filled circles) or 11 October 2002 (open circles) and (a) percentage fruit with brown rot for no fungicide trees or (b) percentage fruit with bacterial infection for no bactericide trees. Dotted lines show the $95 \%$ simultaneous confidence intervals for the regression lines. Note the square-root scale on the horizontal axis. 


\section{DISCUSSION}

NZFT is the dominant thrips species responsible for damage to nectarines in Central Otago. A high proportion (23\%) of other species was recorded in 2001 but similar seasonal variation in species abundance has been observed previously (McLaren 1992). The presence of $F$. occidentalis on nectarine flowers was a new record for New Zealand.

There was wide variation in thrips numbers per tree (Fig. 1) but this was not unexpected, given that half of the trees had been treated with insecticide and NZFT is very mobile (McLaren \& Fraser 2002). The analysis of cumulative thrips counts in relation to brown rot showed significant correlations with cumulative numbers at the start of the second generation but not at its end. Possibly later infestations did not coincide with the more susceptible flowering stage for brown rot infection. The correlation between early thrips numbers and brown rot seemed to be contradicted by the absence of a relationship between the insecticide programme and brown rot at harvest. It therefore remains undetermined whether an insecticide programme would improve the level of control of brown rot, especially when conventional fungicides are being used.

Bacterial pathogens are very active on summerfruit in spring (Young 1987) and could be expected to be transported by thrips at that time. The absence of bacterial spot in 2002/03 may explain why there was no significant correlation between bacterial infections and cumulative thrips numbers in 2002 when there had been in 2001. It suggests that thrips could vector bacterial spot but not bacterial blast, but this requires further investigation.

\section{CONCLUSION}

NZFT appears to be capable of vectoring brown rot during the flowering and early fruitlet stages but the mechanism involved in disease transmission has not been examined and requires further research. NZFT may also vector bacterial disease, particularly bacterial spot, but this effect was seen in only one year. Since the insecticide programme did not reduce the level of brown rot, it is not recommended that insecticides be used to augment fungicidal control. Further investigation is needed to determine whether an insecticide programme applied during flowering reduces brown rot in situations where conventional fungicides are not applied, as in organic nectarine orchards where oil is sometimes used to control thrips.

\section{ACKNOWLEDGEMENTS}

The authors thank Peter Lo and Philip Elmer for editorial comment. Funding for this research was provided by the New Zealand Foundation for Research, Science and Technology.

\section{REFERENCES}

Ananthrakrishnan, T.N. 1980: Thrips. In: Harris, K.E.; Maramorosch, K. ed. Vectors of Plant Pathogens. Academic Press, New York. Pp. 149-164.

Bailey, S.F. 1935: Thrips as vectors of plant diseases. J. Econ. Entomol. $28: 856$ - 863.

Ellis, E.C.; Penman, D.R.; Gaunt, R.E. 1988: Thrips as potential vectors of brown rot of stonefruit in New Zealand. Proc. $41^{\text {st }}$ N.Z. Weed and Pest Control Conf.: 286-287.

Fermaud, M.; Gaunt, R.E.; Elmer, P.A.G. 1994: The influence of Thrips obscuratus on infection and contamination of kiwifruit by Botrytis cinerea. Plant Path. 43: 953960.

Fermaud, M.; Gaunt, R.E. 1995: Thrips obscuratus as potential vector of Botrytis cinerea in kiwifruit. Mycological Research 99: 267-273.

Lewis, T. 1973: Thrips, their biology, ecology and economic importance. Academic Press, London.

Marullo, R. 1997: The relationship between saprophagy and phytophagy in thrips. Bull. Lab. Ent. Agr. Filippo Silvestri 53: 19-24.

McLaren, G.F. 1992: Thrips on nectarines in the spring. Proc. 45th N.Z. Plant Prot. Conf: : 111-115. 
McLaren,G.F.; Fraser, J.A. 2000: Development of thresholds for insecticidal control of New Zealand flower thrips on nectarines in spring. N.Z. Plant Prot. 53: 194-199.

McLaren, G.F.; Fraser, J.A. 2002: Diurnal activity of New Zealand flower thrips on stonefruit in spring and at harvest. In: Marullo, R.; Mound, L. ed. Proceedings of the $7^{\text {th }}$ International Symposium on Thysanoptera. Pp. 269-271.

Michalides, T.J.; Elmer, P.A. G. 2000: Botrytis gray mould of kiwifruit caused by Botrytis cinerea in the United States and New Zealand. Plant Diseases 84 (3): 208 - 223.

Mound, L.A. 2002: So many thrips - so few tospoviruses? In: Marullo, R.; Mound, L. $e d$. Proceedings of the $7^{\text {th }}$ International Symposium on Thysanoptera. Pp. 15-18.

Teulon D.A.J.; Penman D.R. 1994: Phenology of the New Zealand flower thrips Thrips obscuratus (Crawford) (Thysanoptera: Thripidae), on nectarines and peach flowers. N. Z. Entomol. 17: 70-77.

Young, J.M. 1987: Orchard management and bacterial diseases of stone fruit. N.Z. J. Exp. Agric. 15: 257-266. 